\title{
PENGARUH RANGE OF MOTION (ROM) TERHADAP KEKUATAN OTOT EKSTREMITAS PADA PASIEN STROKE DI RS PUSAT OTAK NASIONAL (PON)
}

\author{
Dewi Nur sukma Purqoti \\ STIKE YARSI Mataram \\ Email: purqotidewi87@gmail.com)
}

\begin{abstract}
Abstrak
Latar belakang: Stroke adalah gangguan peredaran darah otak yang menyebabkan defisit neurologis mendadak sebagai akibat iskemia atau hemoragi sirkulasi saraf otak. Data di Amerika Serikat menunjukkan pada tahun 2008 stroke merupakan penyebab kematian keempat pada orang dewasa dan penyebab kecacatan dalam jangka waktu panjang. Gejala paling khas adalah cenderung mengalami hemiparesis atau kelemahan otot. Salah satu yang bisa dilakukan untuk meningkatkan kekuatan otot pasien strok adalah dengan melalukan latihan gerak atau disebut juga dengan range of motion (ROM). Tujuan: Penelitian ini mempunyai tujuan untuk mengetahui pengaruh Range of Motion (ROM) terhadap kekuatan otot ekstrimitas pada pasien stroke. Metode: Desain yang digunakan penelitian adalah Quesi_Experimental dengan pendekatan one group pre post test designe. Jumlah sample sebanyak 10 orang dengan menggunakan teknik Purposive Sampling Alat pengumpulan data pada peneliian ini menggunakan lembar observasi. Analisis data meggunakan paired t tes. Hasil: Hasil penelitian menunujukkan bahwa responden sebagian besar berumur $>60$ tahun (60\%), berjenis kelamin laki-laki (50\%) dan perempuan (50\%), dan semuanya menderita stroke non hemoragik. Sebelum dilakukan terapi ROM, derajat kekuatan otot pasien termasuk kategori derajat 0 hingga derajat 2 . Dan sesudah dilakukan terapi ROM, derajat kekuatan otot pasien termasuk kategori derajat 2 hingga derajat 4. Simpulan: Terdapat perbedaan (peningkatan) derajat kekuatan otot pasien sebelum dan sesudah terapi ROM dengan nilai $p=0,000<0,05$. Terapi ROM dinyatakan efektif dalam meningkatkan kekuatan otot ekstremitas penderita stroke
\end{abstract}

Kata Kunci : Kekuatan otot, range of motion (ROM), Stroke

\section{PENDAHULUAN}

Stroke merupakan penyebab kematian nomor dua di dunia setelah penyakit jantung, juga merupakan penyebab kecacatan nomor satu baik di negara maju maupun di negara berkembang (America Heart Assosiation (AHA, 2010). Data dari WHO juga menjelaskan bahwa Badan Kesehatan se-Dunia (WHO) memperkirakan sekitar 15 juta orang terkena stroke setiap tahunnya. Stroke merupakan penyebab kematian utama urutan kedua pada kelompok usia diatas 60 tahun. Negara-negara miskin dan berkembang, seperti Indonesia, insiden stroke cenderung meningkat setiap tahunnya meskipun sulit mendapat data yang akurat (Ginanjar, 2009).

Data di Amerika Serikat menunjukkan pada tahun 2008 stroke merupakan penyebab kematian keempat pada orang dewasa dan penyebab kecacatan dalam jangka waktu panjang (Fang, Shaw\& George, 2012).Setiap tahunnya sekitar 795.000orang Amerika menderita stroke baru atau berulang (America Stroke Assosation (ASA), 2012).Menurut Riset Kesehatan Dasar (2008), prevalensi stroke di Indonesia pada tahun 2007 sebesar 8,3 per 1000 penduduk dan pada tahun 2011 stroke menjadi peringkat penyebab kematian pertama di Indonesia.Range of motion adalah latihan gerakan sendi yang memungkinkan terjadinya kontraksi dan pergerakan otot, dimana klien menggerakan masing-masing persendiannya sesuai gerakan normal baik secara aktif ataupun pasif.(Potter dan Perry (2006).

Berdasarkan Penerapan Havid Maimurahman dan Cemy Nur Fitria tentang keefektifan Range Of Motion terhadap kekuatan otot ekstrimitas pada pasien stroke. Untuk itu hendaknya perawat memberikan asuhan keperawatan untuk mencapai kesehatan pasien yang optimal antara lain memberikan latihan Range Of Motion kepada penderita stroke non hemoragic untuk mengoptimalkan kesembuhannya. Berdasarakan latar belakang dan informasi diatas penulis tertarik melakukan riset tentang pengaruh Range Of Motion (ROM) terhadap kekuatan otot ekstrimitas pada pasien stroke. 


\section{METODE}

Desain yang digunakan penelitian adalah Quesi_Experimental dengan pendekatan one group pre post test designe. Jumlah sample sebanyak 10 orang dengan menggunakan teknik Purposive Sampling.

Data yang dikumpulkan terdiri dari karakteristik responden berupa usia, jenis kelamin, kekuatan otot dan jenis stroke yang di derita. Data dikumpulkan mempergunakan lembar observasi dan pengukuran kekuatan otot menggunakan MMT (Manual Muscle Testing). Analisis data dilakukan secara univariat dan bivariat dengan menggunakan meggunakan paired $t$ tes

\section{HASIL}

1. Distribusi Responden Berdasarkan Usia Tabel 3.1Distribusi Responden Berdasarkan Usia Pada pasien dengan stroke non hemoragik di RS PON jakarta Timur

\begin{tabular}{ccc}
\hline Usia & Jumlah & $(\boldsymbol{\%})$ \\
\hline$<50$ Tahun & 3 & 10 \\
$50-60$ tahun & 1 & 10 \\
$>60$ tahun & 6 & 10 \\
\hline Total & 10 & 100
\end{tabular}

Tabel $3.1 \quad$ Distribusi Responden

Berdasarkan Usia. Ada 3 pasien $(30 \%)$ yang berumur kurang dari 50 tahun. Ada 1 pasien $(10 \%)$ yang berumur $50-60$ tahun. Ada 6 pasien $(60 \%)$ yang berumur lebih dari 60 tahun.

2. Distribusi Responden Berdasarkan jenis kelamin

Tabel 3.2 Distribusi Responden Berdasarkan jenis kelamin Pada pasien dengan stroke non hemoragik di RS PON jakarta Timur

\begin{tabular}{lcc}
\hline Jenis kelamin & Jumlah & $(\boldsymbol{\%})$ \\
\hline Laki-laki & 5 & 50 \\
Perempuan & 5 & 50 \\
\hline \multicolumn{1}{c}{ Total } & 10 & 100 \\
\hline
\end{tabular}

Tabel 3.2 memperlihatkan pembagian pasien berdasarkan jenis kelamin. Ada 5 pasien $(50 \%)$ yang berjenis kelamin lakilaki. Ada 5 pasien $(50 \%)$ yang berjenis kelamin perempuan.

3. Distribusi Responden Berdasarkan Derajat kekuatan otot sebelum ROM

Tabel 3. 3 Distribusi Responden Berdasarkan Derajat kekuatan otot Sebelum ROM Pada pasien dengan stroke non hemoragik di RS PON jakarta Timur

\begin{tabular}{|c|c|c|}
\hline Kekuatan otot & Jumlah & $(\%)$ \\
\hline 0 & 3 & 30 \\
\hline 1 & 4 & 40 \\
\hline 2 & 3 & 30 \\
\hline Total & 10 & 100 \\
\hline
\end{tabular}

Tabel 3.3 memperlihatkan pembagian pasien berdasarkan derajat kekuatan otot sebelum dilakukan ROM. Ada 3 pasien (30\%) yang derajat kekuatan ototnya termasuk kategori 0 . Ada 4 pasien $(40 \%)$ yang derajat kekuatan ototnya termasuk kategori 1. Ada 3 pasien (30\%) yang derajat kekuatan ototnya termasuk kategori 2. Pasien dalam penerapan ini sebelum dilakukan terapi ROM, kekuatan ototnya minimal pada derajat Odan maksimal sampai pada derajat mampu menggerakkan sendi dan Tidak dapat melawan gravitasi (derajat 2).

4. Distribusi Responden Berdasarkan Derajat kekuatan otot Setelah ROM

Tabel 3. 4 Distribusi Responden Berdasarkan Derajat kekuatan otot Setelah dilakukan ROM Pada pasien dengan stroke non hemoragik di RS PON jakarta Timur

\begin{tabular}{ccc}
\hline Kekuatan otot & Jumlah & $(\%)$ \\
\hline 2 & 7 & 70 \\
3 & 1 & 10 \\
4 & 2 & 20 \\
\hline Total & 10 & 100 \\
\hline
\end{tabular}

Tabel 3.4 memperlihatkan pembagian pasien berdasarkan derajat kekuatan otot sesudah dilakukan terapi ROM. Ada 7 pasien $(70 \%)$ yang derajat kekuatan ototnya termasuk kategori 2 . Ada 1 pasien (10\%) yang derajat kekuatan ototnya termasuk kategori 3. Ada 2 pasien (20\%) yang derajat kekuatan ototnya termasuk kategori 4. Dengan demikian sesudah dilakukan terapi ROM, ada peningkatan derajat kekuatan otot pada pasien. Sesudah terapi ROM kekuatan ototnya minimal pada derajat mampu menggerakkan persendian dan maksimal pada derajat mampu menggerakan sendi, dapat melawan gravitasi, dan kuat terhadap tahanan ringan.

5. Kekuatan otot sebelum dan sesudah dilakukan ROM

Tabel 3.5 Kekuatan otot sebelum dan sesudah dilakukan ROM Pada pasien dengan stroke non hemoragik di RS PON jakarta Timur

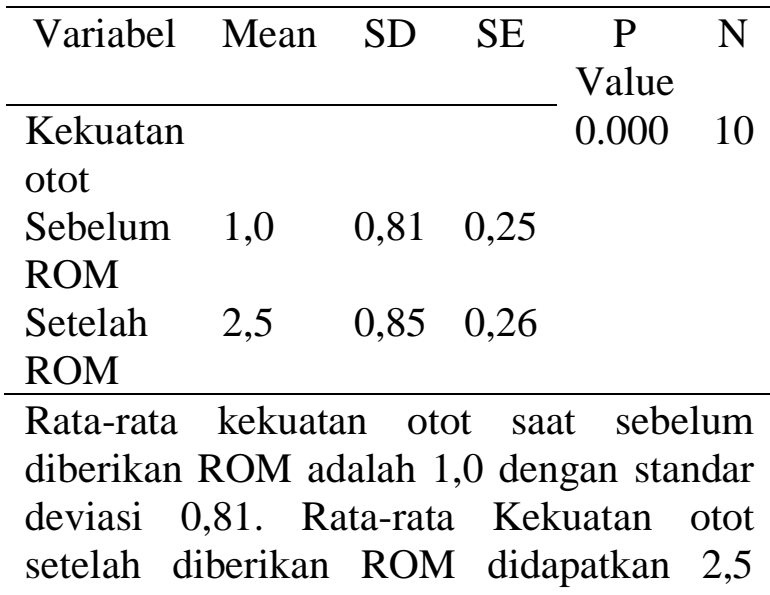


dengan standar deviasi 0,85 . Terlihat nilai mean perbedaaan antara sebelum diberikan ROM dan setelah diberikan ROM adalah 1,5 dengan standar deviasi 0,527 . Hasil uji statistik didapatkan nilai 0.000 maka dapat disimpulkan ada perbedaan yang signifikan antara kekuatan otot sebelum diberikan ROM dengan setelah diberikan ROM.Secara deskriptif diketahui bahwa derajat kekuatan otot sesudah terapi ROM lebih baik dibandingkan sebelum terapi ROM.

\section{DISKUSI}

1. Karakteristik umur responden

Hasil penilitian menunjukan pembagian responden berdasarkan umur. Ada 6 pasien $(60 \%)$ yang berumur $<60$ tahun. Risiko terkena stroke meningkat sejak usia 45 tahun. Setelah mencapai 50 tahun, setiap penambahan usia tiga tahun meningkatkan risiko stroke sebesar 11-20\%, dengan peningkatan bertambah seiring usia. Riwayat stroke dalam keluarga, terutama jika dua atau lebih anggota keluarga pernah mengalami stroke pada usia kurang dari 65 tahun, dapat pula meningkatkan risiko terkena stroke.

\section{Karakteristik jenis kelamin responden}

Hasil penelitian memperlihatkan pembagian responden berdasarkan jenis kelamin yaitu ada 5 pasien $(50 \%)$ yang berjenis kelamin laki-laki, dan 5 pasien (50\%) yang berjenis kelamin perempuan.

\section{Karakteristik kekuatan otot responden}

Hasil penerapan yakni derajat tingkat kekuatan otot sebelum dilakukan tindakan ROM ada 4 pasien (40\%) yang derajat kekuatan ototnya termasuk kategori 1. Pasien dalam penerapan ini kekuatan ototnya minimal pada derajat 0 , tidak adanya kontraksi otot, dan maksimal sampai pada derajat mampu menggerakkan sendi dan tidak dapat melawan gravitasi, sedangkan hasil penerapan dari derajat tingkat kekuatan otot setelah dilaukan tindakan ROM ada 7 pasien $(70 \%)$ yang derajat kekuatan ototnya termasuk kategori 2. Sesudah dilakukan terapi ROM, ada peningkatan derajat kekuatan otot pada pasien. Kekuatan ototnya minimal pada derajat mampu menggerakkan persendian dan maksimal pada derajat mampu menggerakan sendi, dapat melawan gravitasi, dan kuat terhadap tahanan ringan.

Tujuan rehabilitasi untuk pasien stroke adalah membantu pasien untuk mendapatkan kemandirian maksimal dan rasa aman saat melakukan aktivitas sehari- hari. Latihan ROM merupakan bagian dari proses rehabilitasi untuk mencapai tujuan tersebut. Latihan beberapa kali dalam sehari dapat mencegah terjadinya komplikasi yang akan menghambat pasien untuk dapat mencapai kemandirian dalam melakukan fungsinya sebagai manusia. Latihan ROM dikatakan dapat mencegah terjadinya penurunan fleksibilitas sendi dan kekakuan sendi.

Sesudah dilakukan terapi ROM, seluruh pasien mengalami peningkatan derajat kekuatan otot. Derajat kekuatan otot pasien menjadi berkisar antara derajat 2 (mampu mengerakkan persendian, tidak dapat melawan gravitasi) hingga derajat 4 (mampu menggerakan sendi, dapat melawan gravitasi, kuat terhadap tahanan ringan). Uji statistik menunjukkan bahwa perbedaan derajat kekuatan otot sebelum dan sesudah terapi ROM termasuk signifikan $(\mathrm{p}=0,000<0,05)$ yaitu ada perbedaan yang bermakna. Kesimpulkan dari hasil penerapan bahwa terapi ROM memang efektif meningkatkan derajat kekuatan otot ekstremitas penderita stroke.

Temuan dalam penerapan ini mendukung konsep terapi ROM sebagai alat efektif untuk meningkatkan kekuatan otot ekstremitas penderita stroke. Tujuan ROM sendiri adalah mempertahankan atau memelihara kekuatan otot, memelihara mobilitas persendian, merangsang sirkulasi darah, mencegah kelainan bentuk.

\section{SIMPULAN}

1. Pasien penderita stroke di ruang 7A dan 7B yang menjadi sample penelitian ini sebagian besar berumur >60 tahun $(60 \%)$, berjenis kelamin laki-laki $(50 \%)$ dan perempuan $(50 \%)$, dan semuanya menderita stroke non hemoragik.

2. Sebelum dilakukan terapi ROM, derajat kekuatan otot pasien termasuk kategori derajat 0 (tidak ada gerakan otot sama sekali) hingga derajat 2 (mampu menggerakan sendi, tidak dapat melawan gravitasi).

3. Sesudah dilakukan terapi ROM, derajat kekuatan otot pasien termasuk kategori derajat 2 (mampu mengerakkan persendian, tidak dapat melawan gravitasi) hingga derajat 4 (mampu menggerakan sendi, dapat melawan gravitasi, kuat terhadap tahanan ringan).

4. Terdapat perbedaan (peningkatan) derajat kekuatan otot pasien sebelum dan sesudah terapi ROM dengan nilai $p$ $=0,000<0,05$. Terapi ROM dinyatakan 
efektif dalam meningkatkan kekuatan otot ekstremitas penderita stroke.

\section{DAFTAR PUSTAKA}

Adams, et al., (2007). American of Academy of Neurology affirms the value of this guidelineasanQuality of Care Outcomes in Research Interdisciplinary Working. Groups. Stroke,;38:16655-1771.

Ariawan, Iwan (2005). Besar dan metode sampel pada penerapan kesehatan. Fakultas Kesehatan Masyarakat Universitas Indonesia.

Bararah, T. (2013). Asuhan Keperawatan Panduan Lengkap Menjadi Perawat Profesional. Jilid 1 prestasi pustakarya: Jakarta

Brunner dan Suddarth, (2008). Keperawatan Medikal-Bedah. Jakarta:EGC.

Depkes RI, (2006) Pedoman Nasional Penanggulangan Tuberculosis, Cetakan ke-10, Jakarta.

Guyton, Arthur C. (2007). Buku Ajar FisiologiKedokteran. Jakarta: EGC.

Hastono, Sutanto Priyo \& Sabri, Luknis (2010). Statistik kesehatan. Jakarta: Raja Grafindo Persada.
Hastono, Sutanto Priyo (2010). Analisis data kesehatan. Depok: Fakultas Kesehatan Masyarakat Universitas Indonesia.

Hidayat, Aziz Alimul. (2007). Riset keperawatan dan teknik penulisan ilmiah. Jakarta: Salemba Medika.

Maimurrahman, H., \& Fitria, C.N .(2006). Keefektifan Range Of Motion (ROM) tehadap kekuatan otot ekstrimitas pada pasien stroke.di akses tanggal 6 desember 2015.

Nurarif, A.H. (2015). Aplikasi Asuhan Keperawatan Berdasarkan Diagnosa Medis dan Nanda NIC-NOC. Edisi Revisi Jilid 3: USA

Suryanto, (2011). Metodologi dan Aplikasi Penerapan Keperawatan.Yogyakarta: Nuha Medika.

Valente et al. (2015). Ischemic Stroke Due to Middle Cerebral Artery M1 Segment Occlusion: Latvian Stroke Register Data. Proceedings of the Latvian Academy of Sciences, Volume 69, Issue5, Pages 274277. Diakses pada 21 Januari 2016 pada http://www.degruyter.com/view/j/prolas. 2015.69.issue5/prolas-2015-0042/prolas2015-0042.xml

WHO. Maternal Mortality: World Health Organization; 2014 